\title{
Accounting engineering for sustainable development
}

\author{
A. Sidornya ${ }^{1, *}$ \\ ${ }^{1}$ Don State Technical University, Rostov-on-Don, Russia
}

\begin{abstract}
The article deals with the sustainable development of industrial enterprises in Russia, accounting for sustainable industrial growth of the national economy, tools of accounting engineering aimed at creating an information basis of transformation the Russian economic model to knowledge based economy. The proposed mechanism of ownership control of industrial enterprises in the context of long-term planning of the national economy. Theoretical bases of accounting engineering, its tools are defined. A brief review of the literature on the problem of accounting engineering is provided. A practical example of the application of the accounting engineering logic for the industrial enterprise is reviewed. It describes the research results obtained during the last 25 years of Russian scientific school of accounting engineering. Conclusions and recommendations on the use of accounting engineering to sustainable development of the Russian economy are formulated.
\end{abstract}

\section{Introduction}

Drivers of modern economy essentially differ from economy of last century. If power of industrially developed countries consisted in the recent past in physical resources, today, significant natural resources make the Russian economy weakness and vulnerable. The fact is that the vast natural resources of Russia for a long time compensated the low economic efficiency, low labor productivity, an unacceptable level of corruption, and low quality of decision-making. Is no more than several of Russian companies, which management has a sufficiently high level (Wimm Bill Dann, Tinkof Bank, Ozone, Magnet, Yandex, ABBYY, Sberbank), but majority of them senior management formed by foreigners. This situation is unacceptable for Russia, in which the higher education level was high enough in the Soviet period. However, the problem of quality of managers' education - is not the only one. There is an urgent problem of the quality of management information support - quality economic, and first of all accounting, information.

Accounting education in Russia has transformed in the last few years. Russia goes to the international financial reporting standards (IFRS). The IFRS course is included into the basic program of a bachelor degree of financial accounting.

Programs of advanced training of professional accountants are also provided by studying of last modifications of IFRS. However, IFRS is not a "cure against all diseases" of the national economy. Using IFRS as the basis for the design of management accounting systems, as suggested by some authors in Russia - is inappropriate, because management accounting cannot be placed in any frame.
Solving the problem of improving the quality information support of decision makers is beyond the scope of IFRS. This problem is in the area of trade secrets, insider information and engineering of company's business processes. This problem cannot be solved by the implementation of any kind, even the best (IFRS), mandatory standards. Each company has its own unique culture, strategy, business model, organizational model, life cycle phase, the production cycle, business process maps, assets portfolio, the relation with consumers, structure of financing, etc. And each company has its own unique characteristic of the needs for management information. That is why in the last 25 years in Russia the scientific school of "accounting engineering", which main concept is the design of management accounting under the specific company based on the "structured working chart of accounts" and tools of "derivative balance statements", was widely adopted.

Despite the fact that the terminology "accounting engineering" carries a "technical" context and the school promotes the widespread use of instruments of exact sciences: graph theory, the adjacency matrix, algorithms, fractals, patterns, etc. The main goal of accounting engineering is add more economy in the accounting.

Throughout the last century accounting has steadily lost its economic nature turning into political science. People who were born in the Soviet Union know the famous saying of Lenin: "Socialism - it is accounting." These people do not need to explain how much accounting can be politicized (enough only to remember the experiment undertaken in the Soviet Russia on transition from the monetary measuring to the «workdays» in accounting). However, the market economy countries accounting is politicized too. So

Corresponding author: gorodrostov@gmail.com 
one of the famous accountants A. Hopwood 30 years ago wrote: Accounting begins to be considered more and more as a social but not simply technical phenomenon. Although slowly, but begin to take into consideration of his origin and that it gives the environment [1]. Accounting researchers have long been interested in the extent to which politics affects accounting standard-setting. Even casual observation of the standard-setting process suggests that politics can have a first order effects on how accounting standards are set. Beginning with Watts [2] and Watts and Zimmerman [3], researchers have sought to develop and test economics-based theories of standard-setting that capture these political forces [4].

What kind of impact the policy has had on accounting?

One of the most striking examples of the impact of policy on accounting is its division into types: financial and tax. This division is purely political and designed to provide the ability to manipulate numbers. Let's assume that the enterprise earned profit, there are 4 participants who agreed to divide it equally on $25 \%$. And so, for one of participants the accountant counted profit in the amount of $\$ 100$ and paid $\$ 25$ of dividend, for another he counted profit in the amount of $\$ 40$ and paid $\$ 10$ dividends, for the third counted profit in the amount of $\$ 10$ and paid $\$ 2,5$ dividends, and for the last the profit made $\$ 4$ and respectively dividends - $\$ 1$. All received on $1 / 4$ profits. All is the fair. However the first received $\$ 100$ and the last $\$ 1$.

Do everything is fair? Whether it is possible to manage the enterprise on the basis of accounting information driven by political expediency?

School of Accounting Engineering, no claim to absolute truth, attempts to reduce the all variety of economic transactions and accounting entries of economic actors to the highest degree of abstraction: property, risks, reserve system, intellectual capital, a margin of synergy safety, a zone of financial risk, etc. on the basis of the most demanded achievements of economic science: theory of the firm, transaction cost theory, agency theory, stakeholder theory, the concept of sustainable development and others.

\section{Overview of literature}

The theoretical basis of accounting engineering was developed mainly English-speaking researchers J.Briloff [5], M. Schilit [6], R. Parker [7], J. Griffith [8], J. Elliot [9], which circle of scientific interests stretched generally for earning management and socalled "creative accounting".

At the same time, its methodological basis comes from Germany, where engineering mechanisms of accounting control: "zero derivative balance statements" is widely adopted. Which purpose is "a reflection of the relations of property and debt after the closing of accounts" that would "give at the end of the reporting period, a reliable estimate of property status enterprise "[10]. Such famous German scientists as Willenbucher [11], Kayser [12], Simon
[13], and Beigel [14], were ideologists of inventory approach and an valuation of assets at current value. In the end, the Higher Court of Germany (RG) has become for these positions noting that "the practice of leaving in the balance sheet at the acquisition price paid by the flawed"[15].

However, it should be noted that the term "accounting engineering" in these papers are not used. The term "accounting engineering" appeared in the late twentieth century in in the works of C. Drury, A. Kure, M. Capron [16]. So Alan Kure identified of financial engineering instruments and devices (balance engineering and engineering of cash flows) [17].

In Russia the first who used the term "accounting engineering" was the famous Russian scientist, the founder of the scientific school of accounting engineering, Viktor Tkach. In 1993 he goes from Rostov State University of Economics, where he as an assistant professor at the Department of Accounting, to Rostov State University of Civil Engineering (RSUCE). Here, in his own words, he "faced with a completely different, engineering, thinking" [18]. Since 1993, Viktor Tkach created a scientific school where adherents of more than 100 are unique scientists today: the authors of dissertations, numerous articles and monographs. V. Tkach is the author qualimetrical textbook "Accounting engineering theory"[19], monographs "Accounting engineering: concept, theory and practice", "The theory, systems and models of accounting engineering network" and more than 200 publications.

Terminology "accounting engineering" found in recent English-language studies. So P.D. Nicoleta claims that accounting engineering and creative accounting is the same, and their only distinction lies for the purpose of these types of accounting [20]. L. Michalczyk argues that «accounting engineering legally accepted manipulation of the financial result by interested parties - is a serious problem for the economy» [21]. And M. R. Young in general claims that good news is that accounting engineering - is rather difficult in application [22].

It is possible to note that now the term "accounting engineering" reliably entered in Russian-speaking and English-speaking economic literatures. But the negative context that is embedded in the Englishspeaking authors it is not typical for Russia. Moreover in Russia to use the balance of engineering tools is seen approaching the objects of accounting control to the true economic values.

\section{Setting of a problem}

The concept of accounting engineering was the response to excessive politicization of financial accounting. Even in 1973, the American professor C.T.Hongren wrote that the accounting standards being burrows limit the social behavior of economic agents, and later they should be accepted and other sectors of society. This acceptance can be forced or 
voluntary. In a democratic society to achieve the consent is particularly difficult [23]. And in 1991, also American Professor Parker writes, "Accounting is a social network, enclosing a very significant consensus"[24].

However, at the same time, a political consensus is embodied in accounting further alienates him from his economic substance. It must to say that this process is inevitable: the object of accounting is a property, and property is political category. Therefore, the economy and politics are inseparable. Recent events around the sanctions against Russia are the clearest example of that. However, Russia's problems are more related not to the sanctions, it related with finiteness of its development model built on the basis exhaustible natural resources. That it is not possible to ensure the sustainability of its development.

However, the problem of sustainability has several dimensions: political stability, economic stability, demographic stability, environmental sustainability, institutional sustainability. Accounting engineering makes complex impact on all above-named elements of a sustainable development: the economic - through risk control, reserve system and strategy of development; the political - through justice of distribution of value in current generation; the demographic - through ensuring justice of distribution of value between generations; the ecological - through ensuring safety of an ecosystem (the natural capital); the institutional - through ensuring safety of the property rights. But all of this, - is only return to the economic origins of the accounting.

\section{Theoretical essays}

Problem of excessive politicization of accounting led to the fact that in order to return him to the economic substance is necessary to redesign it. It is the task of accounting engineering. So, Michalczuk writes that a theoretical basis of accounting engineering is the combination:

a) kuhn's post-constructivist anti-cumulativism - to the extent to which it establishes a theoretical basis for observation and refutes the idea that science is merely a system for collecting knowledge,

b) general systems theory - its theory of sciences and the logic of argumentation based on the principles of causality,

c) earnings management - to the extent it combines accounting and company management,

d) agency theory and the theory of transaction costs - as far as management and organizational sciences are concerned,

e) prospect theory - as far as defining key concepts used for describing, classifying and measuring values is concerned, detailed accounting theory - as a basis for analysis within the variant accounting framework, as well as the analysis of earnings and outgoings flow, the notions of accountability and responsibility - to determine who is responsible for the quality of information generated by means of variant accounting [21].
At the Russian school select the following basic concepts, theories and mechanisms of accounting engineering:

a) General Systems Theory (Bertalanffy L., Tkach V., etc.);

b) Theory of the firm (Coase R., Maksimenko A., etc.);

c) The agency theory (Eisenhardt K., Kurseev D., etc.);

d) Stakeholder theory (Freeman E., Pavlenko I., etc.);

e) The concept of sustainable development (Barbier E., Sidornya A.[25], etc.);

f) Situationally - matrix simulations (Sorter G., Kolvakh O., etc.);

g) The fractal theory (Barnsley M., Krohicheva G., etc.);

h) Behavioristic theory (Watson J., Grafova T., etc.);

i) Stochastic analysis (Howard M., Lesniak V., etc.);

j) The theory of network efficiency (Castells M., Arkhipov E, etc.);

k) The theory of constraints (Goltratt E., Aksenova, etc.);

1) The theory of synergism (Geneen H., Sidornya A., etc.);

m) The theory of economic cycles (Schumpeter J., Bogataya I., etc.);

n) The all-inclusive income concept (Hendriksen E., Sidornya A., etc.);

o) The business modeling concept (Ostervalder A., Sidornya N., etc.);

p) The theory of capital structure, dividend theory (Modigliani F. and Miller M. , Evstafieva E., etc.).

The basis of accounting engineering method is the algorithm of several stages. The first stage is defined by the object of engineering controls: it may be a business process, property, costs, risks, reserves, intellectual capital, a synergistic effect, etc. The next step is designed «structured working chart of accounts» for the primary control of engineering data. The third stage is determined by the initial operator: the balance, chart of accounts chapters, a group of related accounts, mega accounts. Since accounting engineering method is based on the balance it is important that the initial operator balanced. In the fourth step the aggregated entry made on the balance sheet and off balance sheet accounting unaccounted factors influencing the control object. In the fifth stage, made «zero balance» by the hypothetical separate sale of all assets and satisfaction of liabilities. The sixth stage is determined by the fair value of an institutional unit. At the seventh stage, the disaggregation of influence controlled and an uncontrolled factor on object of engineering controls is made.

\section{Practical essays}

Application of accounting engineering is successfully performed at the largest enterprises of the south of Russia various forms of ownership. This tools is effective in both the private (corporate) and the state 
(universities, hospitals, municipal) property. On the platform of accounting engineering in Russia, received more than 160 patents and certificates of registration of computer programs and databases, including the following «derivatives balance sheets»: immunization, monitoring, socio - economic, adaptive, hedged, outsourcing, gradualist, transactional, situational, integrated risk, strategic, subsidiarity, substation, synergistic, fractal, etc.

The internet resource: http: www.resoursum.com provide some accounting engineering tools can be used online. Suppose the net assets of the company amount to $\$ 1,000$. The share capital of $\$ 600$. Its market value is $\$ 1,500$. After putting on entry unrecorded and off-balance liabilities - net assets amounted to $\$ 400$, and after putting on entry unrecorded assets - net assets amounted to $\$ 1,300$. After the procedure of separately hypothetical sale of assets and satisfactions of liabilities to meet debt-free money amounted to $\$ 800$. The following conclusions can be drawn from the above data: : recognized capital gain $(\$ 400(1000-600))$ is actually overestimated by $\$ 200(1000-800)$. Real capital gain amounted of $\$ 900(1500-600)$. Including: the impact of recognized factors of $\$ 200$ (800 - 600), synergetic enterprise security margin of $\$ 700(1500-800)$, where the influence of the engineering factors of $\$ 300$ (1300 - 1000), the impact of uncontrollable factors of $\$ 400$ (700 - 300).

Also in this example, you can keep track of the «rate of current consumption» of the enterprise. It is evident that the company recognized income of $\$ 400$ $(1000-600)$. However, the increase in net assets in the amount of $\$ 300$ upon the registration unaccounted factors, formed as follows: registration with unrecorded liabilities (provision for ecosystem restoration) reduced net assets by $\$ 600$, and registration with unreported assets gave an increase of \$900. «Rate of current consumption» is defined as: the fair value of the company minus the initially invested capital, minus the provision for restoration of ecosystems and is $\$ 300((1500-600)-600))$. This rate shall be distributed among the present generation: the owners and society. In other words, the profit of $\$$ 400 only $\$ 300$ can be directed to the payment of dividends, staff development, social projects and charity. \$ 100 must to be sent to the reserve for ensuring the sustainability development to the point until it is $\$ 600$. Reserve for ensuring the sustainability development should be subject to an annual audit of the need for adjustments.

Depending on what factors are registered in the implementation of engineering transactions by accounting engineering tools can monitor the impact on the sustainability development: risk, reserve, reengineering of business processes, the various risk situations, transaction costs, inflation, changes implemented strategies, changes of property rights, stakeholders, existing restrictions on the use of assets, information and logistics networks, intellectual capital, synergies, cash flow dynamics, government grants and expenses, etc.

\section{Conclusion}

In conclusion, it must be admitted that the management of the considered enterprise has no control over a significant part of the factors that affect the welfare of the owners. But provides a high level of creating new value is sufficient to enable the implementation of current consumption. At the same time, opportunity of increase of efficiency of management decisions its large (unaccounted factors accounted for $\$ 400)$.

However, the lack of practice create reserve for sustainability development, both on the enterprise in this paper, and the vast majority of real-life Russian companies, may result in them becoming a "financial pyramid" in which the amount of current consumption exceeds the rate, and so consumption is made from the capital, and this automatically makes the economic model (business model) - exhaustible. That eliminates the sustainability development in economic and political, demographic, environmental and institutional aspects. It is possible to tell that accounting engineering is urged to evaluate and provide in an explicit form, degree of congruence goals the persons making decisions at all levels of management in private and public sector, to criteria of sustainable development of Russia.

\section{References}

1. S. Burchell, C. Clubb, A. Hopwood, Accounting, Organization and Society, 10, 4, 5-27 (1985)

2. R.L. Watts, Australian Journal of Management, 2, 53-75 (1977)

3. R.L. Watts, J.L. Zimmerman, The Accounting Review, 53, 112-134 (1978)

4. B. Gipper, B. Lombardi, D.J. Skinner, The Politics of Accounting Standard-Setting: A Review of Empirical Research. https://www.business.unsw.edu.au/researchsite/publications-

site/australianjournalofmanagement-site/2013australian-journal-of-management-symposiumsite/Documents/Skinner-ajms-20130612.pdf.

5. A.J. Briloff, Unaccountable Accounting (Harper \& Row, New York, 1972)

6. H.M. Schilit, Financial Shenanigans (McGraw Hill, New York, 2002)

7. R. Parker, C.W. Nobes, Financial Reporting in the United Kingdom and Australia, Comparative International Accounting (Prentice Hall, NJ, 1995)

8. I. Griffiths, Creative Accounting (Sidgwick \& Jackson, London, 1986)

9. B. Elliott, J. Elliott, Financial Accounting and Reporting (Prentice Hall, 2011)

10. C. Garreis, O. Fuchsberger, Das Allgemeine Deutsche Handelsgesetzbuch (Berlin, 1891) 
11. Willenbucher, Das allgemeine Deutshe Handerlsgesetzbuch, mit Ausschlub des Seerechts, fur die Praxis erlautert (Berlin, 1891)

12. P. Kayser, Gesetz, betreffend die Kommanditgesellschaften auf Aktien und die Aktiengesellschaften (Berlin, 1884)

13. H. Simon, Die Balanzen der Aktiengesellschaften (Berlin, 1899)

14. R. Beigel, Das Buchfuhrungsrecht der Aktiengesellschaft (Leipzig, Ludwig Huberti, 1900)

15. Dicision of RG on 1887.

16. I. Tkach, Management accounting of changes (RSUCE, Rostov-on-Don, 2010)

17. Enhancing Shareholder Wealth by Better Managing Busoness Risk. Director General International Federation of Accoutants (New York USA)

18. D. Kurseev, Tkach - founder of the scientific school "Engineering system of accounting, auditing and management in macroeconomics" (AzovPechat, 2015)
19. V. Tkach, Accounting Engineering Theory (Azov, 2013)

20. P.D. Nicoleta, Creative accounting - art. http://www.oeconomica.uab.ro/upload/lucrari/920 071/52.pdf.

21. L. Michalczyk, Financial Internet Quarterly "eFinanse", 8, (2012).

22. M.R. Young, Financial reporting after the subprime crisis: new challenges for audit committees.

http://www.willkie.com/publications/2010/month/ financial-reporting-after-the-subprime-crisis.

23. J. Rishar, Accounting: theory and practice (FiS, 2000)

24. L.D. Parker, Advances in Public Interest Accounting, 4, (1991)

25. A. Sidornya, Social accounting: Theory and practice http://sites.google.com/site/rostovnauka/zurnalnauka-i-praktika/no3-2011. 